Original Research

\title{
UJI AKTIVITAS ANTIBAKTERI FRAKSI N-HEKSAN, ETIL ASETAT dan AIR DAUN LEUNCA (Solanum nigrum $L$ ) TERHADAP BAKTERI (Staphylococus aureus dan Escherichia coli)
}

\author{
ANTIBACTERIAL ACTIVITY TEST OF N-HECTAN FRACTION, ETIL \\ ASETATE and LEUNCA LEAF WATER (Solanum nigrum L) ON BACTERIA \\ (Staphylococus aureus and Escherichia coli)
}

\author{
Emilda Pinarsi ${ }^{1 *}$, Ghalib Syukrilla ${ }^{2}$ \\ Fakultas Farmasi, Universitas 17 Agustus 1945, Jakarta Utara, Indonesia, 14350 \\ *E-mail: emildabkl15@gmail.com
}

Diterima: $18 / 10 / 2019$

Direvisi: 08/11/2019

Disetujui: 27/02/2020

\begin{abstract}
Abstrak
Penyakit infeksi atau penyakit yang disebabkan oleh mikroorganisme merupakan penyakit yang banyak ditemukan di masyarakat. Menurut laporan WHO penyakit infeksi merupakan penyebab kematian terbesar pada anak-anak dan orang dewasa dengan jumlah kematian lebih dari 13 juta jiwa setiap tahun, serta menempati urutan kedua (25\%) setelah kematian yang disebabkan oleh penyakit kardiovaskular (31\%) dari 53,9 juta kasus penyebab kematian di dunia dan menjadi penyebab kematian utama pada anak dibawah umur 4 tahun. Pencegahan terhadap serangan infeksi dapat dilakukan dengan menggunakan antibiotik seiring dengan meningkatnya resistensi bakteri di dunia kesehatan maka perlu adanya penemuan obat baru. Sumber antibakteri baru dapat diperoleh dari senyawa bioaktif yang terkandung dalam suatu tumbuhan salah satunya dari daun leunca (solanum nigrum l) senyawa aktif alkaloid, saponin, tannin, fenolik, flavonoid, triterpenoid, steroid dan glikosida. Penelitian ini bertujuan untuk mengidentifikasi senyawa aktif yang terkandung dalam fraksi etil asetat daun leunca dan mengetahui mekanisme aksi sebagai inhibitor pertumbuhan bakteri Escherichia coli dan Staphylococcus aureus. Tahap awal dimulai dengan metode maserasi, kemudian dilakukan pemisahan senyawa berdasarkan tingkat kepolaran dengan fraksinasi. Hasil fraksinasi diujikan ke bakteri Escherichia coli dan Staphylococcus aureus. Fraksi n-heksan daun leunca memiliki aktivitas antibakteri terhadap Escherichia coli dan Staphylococcus aureus. Hal tersebut dapat dilahat dari hasil pengukuran rata-rata zona hambat yaitu fraksi n-heksan dengan konsentrasi 60 uq.
\end{abstract}

Kata kunci: Daun leunca, Antibakteri, Solanum Nigrum L

\begin{abstract}
Infectious diseases or diseases caused by microorganisms are diseases that are commonly found in the community. According to the WHO report infectious disease is the biggest cause of death in children and adults with a death rate of more than 13 million people each year, and ranks second $(25 \%)$ after death caused by cardiovascular disease (31\%) from 53.9 million cases of death in the world and a major cause of death in children under 4 years. Prevention of infectious attacks can be done by using antibiotics along with the increase in bacterial resistance in the world of health, it is necessary to find new drugs. New antibacterial sources can be obtained from bioactive compounds contained in a plant, one of them from leunca leaves (solanum nigrum l) active compounds alkaloids, saponins, tannins, phenolics, flavonoids, triterpenoids, steroids and glycosides.
\end{abstract}


This study aims to identify the active compounds contained in leunca leaf ethyl acetate fraction and to know the mechanism of action as an inhibitor of the growth of Escherichia coli and Staphylococcus aureus bacteria. The initial stage begins with maceration method, then the compound separation is carried out based on the level of polarity with fractionation. Fractionation results were tested on Escherichia coli and Staphylococcus aureus. The n-hexane fraction of leunca leaves has antibacterial activity against Escherichia coli and Staphylococcus aureus. This can be solved from the measurement results of the inhibition zone, namely n-hexane fraction with a concentration of $60 \mathrm{uq}$.

Keywords: Leunca leaf, Antibacterial, Solanum Nigrum L

\section{PENDAHULUAN}

Penyakit infeksi atau penyakit yang disebabkan oleh mikroorganisme merupakan penyakit yang banyak ditemukan di masyarakat. Menurut laporan WHO penyakit infeksi merupakan penyebab kematian terbesar pada anak-anak dan orang dewasa dengan jumlah kematian lebih dari 13 juta jiwa setiap tahun, serta menempati urutan kedua (25\%) setelah kematian yang disebabkan oleh penyakit kardiovaskular (31\%) dari 53,9 juta kasus penyebab kematian di dunia dan menjadi penyebab kematian utama pada anak dibawah umur 4 tahun. Beberapa penyakit infeksi yang sering dialami oleh masyarakat antara lain penyakit infeksi kulit dan diare. Penyakit diare disebabkan oleh Escherichia coli sedangkan penyakit kulit disebabkan Staphylococcus aureus [1].

Indonesia mempunyai keanekaragaman hayati terbesar kedua setelah Brazil, sehingga menjadikan Indonesia sebagai Negara yang potensial dalam mengembangkan obat herbal yang berbasis tanaman obat yang terdapat di Indonesia. Jauh sebelum pelayanan kesehatan dengan obat-obat modern dengan biaya yang murah mulai diketahui masyarakat. Pengobatan dan penggunaan obat tradisional tersebut merupakan salah satu komponen program pelayanan kesehatan dasar, serta merupakan salah satu alternatif untuk memenuhi kebutuhan dasar dibidang kesehatan [2].

Pemanfaatan tumbuhan sebagai obat tradisional masih digunakan masyarakat di Indonesia terutama didaerah pedesaan yang masih kaya dengan keanekaragaman tumbuhannya. Daun leunca ini biasanya dikalangan masyarakat pedesaan daun leunca dikonsumsi sehari-hari sebagai lalapan. Leunca dalam ilmu taksonomi digolongkan dalam keluarga solanaceae (labu-labuan). Kandungan utama dari tanaman Solanum nigrum L antara lain yaitu Jenis alkaloid pada Solanum nigrum $L$ yaitu solamargin, solasonin, dan solanin [3].

Alkaloid yang terkandung pada daun yaitu solasonin dan solamargin, sedangkan pada buah terdapat solasonin, solamargin, solanin, solanigrin, dan solasodin, serta solanin pada biji tanaman Solanum nigrum L [4].

buah solanum memiliki kandungan metabolit sekunder yaitu alkaloid, saponin, tannin, flavonoid dan steroid. Menurut penelitian [5] menunjukkan bahwa (solanum nigrum L) memiliki aktivitas antibakteri meneliti bahwa ekstrak methanol dari biji Solanum nigrum L menunjukkan aktivitas antibakteri terhadap bakteri Salmonella thypi, Bacilus subtilis, Staphylococus aureus. 


\section{METODE}

\section{Bahan}

Bahan yang digunakan, yaitu daun leunca yang diperoleh dari daerah curup rejang lebong bengkulu, bakteri yang digunakan Escherichia coli, Staphylococcus aureus, etanol 70 $\%$, DMSO, nacl, kloramfenikol, etil asetat, n-heksan, aquadest steril, mouller hinton agar (MHA), Triptic Soya Agar (TSA).

\section{Prosedur Kerja}

\section{Persiapan simplisia}

Simplisia daun leunca yang di peroleh dari curup kabupaten rejang lebong provinsi Bengkulu diperoleh $10 \mathrm{~kg}$, kemudian disortir dipilih daun leunca yang bebas dari jamur dan karakteristik kurang baik pada simplisia, simplisia dicuci bersih. Daun leunca kemudian dirajang membentuk potongan kecil, setelah itu dikerinkan disuhu ruangan sampai kering, lalu dihaluskan membentuk serbuk.

Pembuatan ekstrak.

Timbang 1000 gram serbuk daun leunca simplisia kering, kemudian dimaserasi dengan menggunakan pelarut etanol $70 \%$, perbandingan $1: 3$ etanol $70 \%$ selama $3 \times 24$ jam pada suhu kamar. Filtrate kemudian disaring dan diuapkan dengan menggunakan rotary evaporator hingga diperoleh ekstrak kental. Rendemen ekstrak etanol daun leunca dihitung dengan membandingkan bobot awal simplisia dengan bobot akhir ekstrak yang dihasilkan (Lestari, 2015). Rendemen

Perhitungan randemen ekstrak daun leunca diperoleh dari berat ekstrak daun leunca yang dihasilkan dibagi dengan berat daun leunca yang digunakan Perhitungan :

$$
\text { Randemen }=\frac{\text { berat ekstrak etanol }}{\text { berat serbuk simplisia }} \times 100 \%
$$

\section{Fraksinasi}

Ekstra kering daun leunca yang diperoleh ditimbang 30 gram menggunakan pelarut yaitu dengan perbandingan 1:3 kemudian difraksinasi dengan campuran n-heksan dipisahkan lapisan Aquadest dengan cara menuangkan dari corong pisah ke erlenmenyer, Ekstrak daun leunca yang telah disari dengan n-heksan dilanjutkan difraksi dengan etil asetat, dimasukan etil asetat dengan cara menuangkan dari corong pisah ke erlenmenyer, selanjutnya fraksi dengan aquadest setelah terbentuk lapisan pisah kan fraksi aquadest dan kemudian menuangkan kedalam erlenmenyer, Ekstrak hasil fraksinasi dipekatkan dengan penganas air sehingga diperoleh bentuk fraksi kental.

\section{Strerilisasi Alat dan Bahan}

Alat-alat gelas yang akan digunakan terlebih dahulu dicuci bersih dan dikeringkan, lalu dibungkus dengan kertas Koran, kemudian disterilkan dalam autoklaf pada suhu $121^{\circ} \mathrm{C}$ dan tekanan 2 atm selama 60 menit. Sedangkan sengkelit/ose dapat disterilkan dengan lampu spiritus hingga kawat sengkelit berpijar merah membara. 
Sterilisasi untuk Laminar Air Flow (LAF) dengan cara menyemprotkan seluruh bagian LAF dengan alkohol 70\% dan disinari dengan lampu UV selama 30-60 menit [6].

\section{Pembuatan Larutan dan Media}

Media agar miring Triptic Soya Agar (TSA) Timbang seksama 1,35 gram TSA, dilarutkan dalam $30 \mathrm{ml}$ aquadest. Media TSA diaduk dan dipanaskan hingga larut sempurna, masukan $7 \mathrm{ml}$ media TSA ke dalam masing-masing tabung reaksi yang telah ditutup dengan kapas. Media disterilkan dalam autoklaf. Hasil sterilisasi media TSA, tabung reaksi dimiringkan untuk media TSA siap digunakan untuk pembiakan bakteri, Staphylococcus aureus dan Escherichia coli.

Media Mueller Hinton Agar.

Ditimbang dengan seksama 1,35 gram MHA, dimasukan kedalam erlenmenyer dan dilarutkan dalam $30 \mathrm{ml}$ aquadest. Media MHA diaduk dan dipanaskan hingga larut sempurna, media MHA disterilkan dalam autoklaf. Hasil sterilisasi media MHA, masingmasing $10 \mathrm{ml}$ MHA dimasukan kedalam cawan petri secara aseptis. Media MHA siap digunakan untuk pengujian aktivitas antibakteri.

\section{Inokulasi}

Bakteri murni (Staphylococcus aureus dan Escherichia coli) yang akan digunakan untuk pengujian aktivitas antibakteri, diinokulasi menggunakan sengkelit/ose dalam media agar TSA secara aseptis dalam Laminar Air Flow (LAF). Kemudian diinkubasi dalam inkubator pada suhu $37^{\circ} \mathrm{C}$ selama 24 jam.

\section{Pengenceran Larutan Uji dari Masing-Masing Fraksi}

Masing-masing hasil fraksi dan hasil ekstrak etanol 70\%daun leunca dengan DMSO 1 gram/mL kocok hingga homogen.

\section{Uji Aktivitas Antibakteri}

Prinsip metode difusi cakram ini digunakan untuk mengukur zona hambat pertumbuhan bakteri yang terjadi akibat difusi zat yang bersifat sebagai antibakteri didalam media padat dengan cara mengambil sebanyak 15-20 ml media MHA yang sudah disiapkan dan steril dalam erlenmenyer, biar kan hingga suhu $45-50^{\circ} \mathrm{C}$. bakteri Escherichia coli dan Staphylococcus aureus yang telah disuspensi sebelumnya sebanyak 1-2 ose dari biakan murni, selanjutnya bakteri ini disebar menggunakan kapas lidi steril diatas media MHA, selanjutnya lakukan pengulangan untuk cawan petri yang berisi media MHA dan TSA.

Pengujian dilakukan dengan cara menggunakan kertas cakram yang sudah ditetesi ekstrak dan fraksi n-heksan, etil asetat, aquadest daun leunca tiga tetes $(60 \mu 1)$, Untuk kontrol negatif digunakan DMSO (dimetil sulfoksida) dan untuk kontrol positifnya digunakan antibiotik kloramfenikol. Kemudian ditempelkan pada permukaan MHA yang telah dioleskan dengan bakteri. Selanjutnya masukan media tersebut ke dalam inkubator dengan suhu $37^{\circ} \mathrm{C}$ selama 24-48 jam. Setelah itu dilakukan pengukuran diameter zona hambat dengan 
menggunakan jangka sorong dengan ketelitian $0,01 \mathrm{~mm}$ dan daerah zona hambat diukur sesuai dengan metode pengukuran. Pengujian ini dilakukan sebanyak tiga kali pengulagan.

\section{HASIL DAN PEMBAHASAN}

\section{Analisis Data}

Data pada penelitian didapat dengan cara mengukur hasil rata-rata zona hambat disekitar kertas cakram berisi larutan hasil fraksi ekstrak daun leunca terhadap bakteri Staphylococcus aureus dan Escherichia coli.

\section{Hasil Uji Daya Hambat}

Penentuan uji daya hambat untuk mengetahui daya hambat dari ketiga fraksi daun leunca yang dapat menghambat pertumbuhan bakteri. Penentuan uji daya hambat dilakukan dengan metode cakram dengan menggunakan media

MHA.

Tabel 1. Daya Hambat Fraksi N-heksan, Fraksi Etil asetat dan Fraksi air terhadap Staphylococus aureus.

\begin{tabular}{|l|c|c|c|c|}
\hline \multicolumn{5}{|c|}{ Diameter zona hambatan } \\
\hline No & $\begin{array}{c}\text { Pengulangan } \\
\text { I }\end{array}$ & $\begin{array}{c}\text { Pengulangan } \\
\text { II }\end{array}$ & $\begin{array}{c}\text { Pengulangan } \\
\text { III }\end{array}$ & Rata-rata \\
\hline Kontrol (+) & 18,61 & 16,59 & 19,77 & 18,33 \\
\hline Kontrol (-) & - & - & - & - \\
\hline Ekstrak & 9,17 & 8,92 & 10,31 & 9,46 \\
\hline Fraksi n-heksan & 9,78 & 11,23 & 12,96 & 11,32 \\
\hline Fraksi etil asetat & 12,30 & 9,85 & 12,08 & 9,75 \\
\hline Fraksi aquadest & 9,22 & 7,80 & 9,16 & 8,72 \\
\hline
\end{tabular}




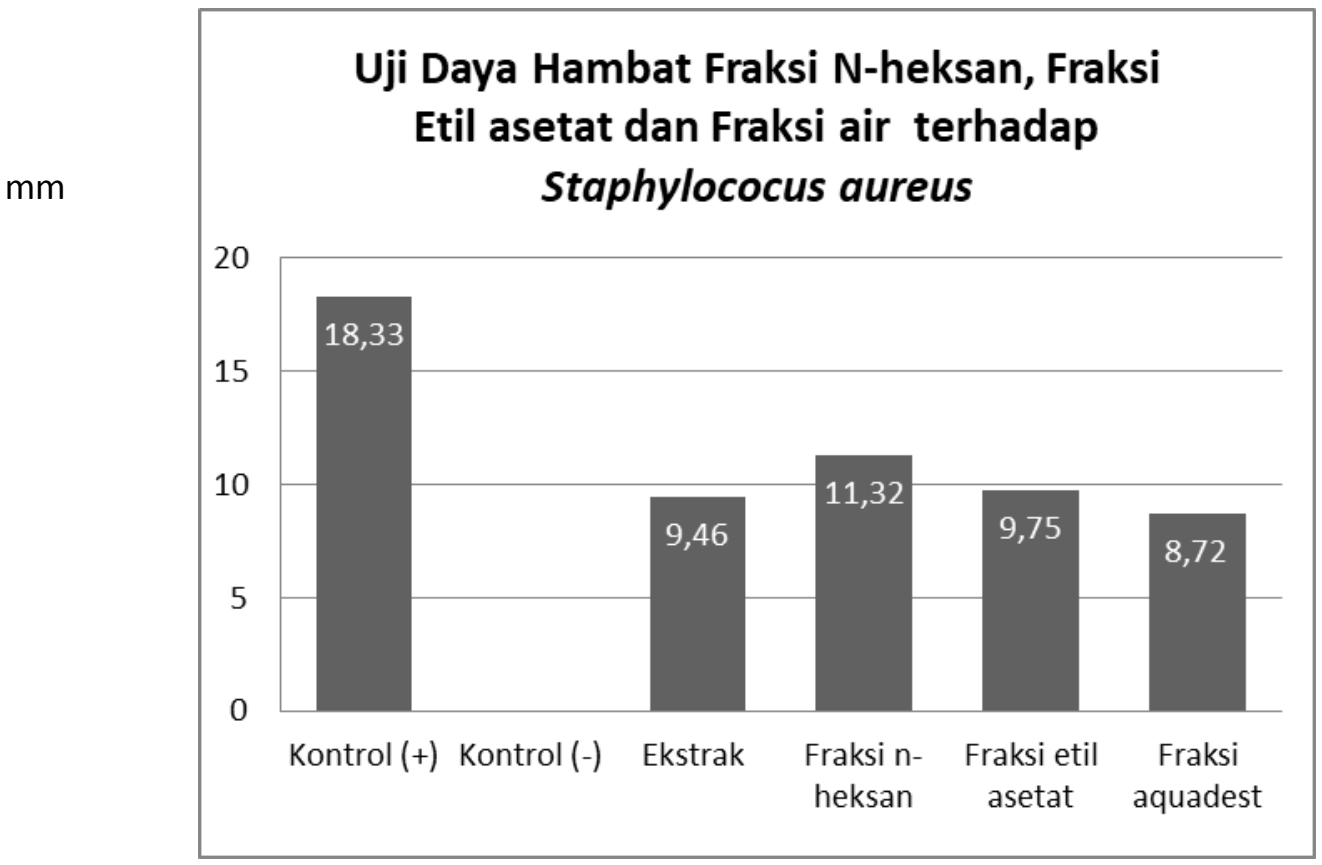

Gambar 1. Diagram uji daya Hambat Fraksi N-heksan, Fraksi Etil asetat dan Fraksi air terhadap Staphylococus aureus

Tabel 2. Daya Hambat Fraksi N-heksan, Fraksi Etil asetat dan Fraksi air terhadap bakteri Escherichia coli

\begin{tabular}{|l|c|c|c|c|}
\hline \multicolumn{5}{|c|}{ Diameter zona hambat } \\
\hline No & $\begin{array}{c}\text { Pengulangan } \\
\text { I (mm) }\end{array}$ & $\begin{array}{c}\text { Pengulangan } \\
\text { II(mm) }\end{array}$ & $\begin{array}{c}\text { Pengulangan } \\
\text { III(mm) }\end{array}$ & Rata-rata \\
\hline Kontrol (+) & 20,61 & 21,63 & 24,47 & 22,23 \\
\hline Kontrol (-) & - & - & - & - \\
\hline Ekstrak & 11,64 & 10,20 & 13,79 & 11,87 \\
\hline F.N-heksan & 13,32 & 13,60 & 18,26 & 15,06 \\
\hline F.Etil asetat & 12,39 & 12,79 & 16,03 & 13,73 \\
\hline F. Aquadest & 9,24 & 10,16 & 7,83 & 9,07 \\
\hline
\end{tabular}




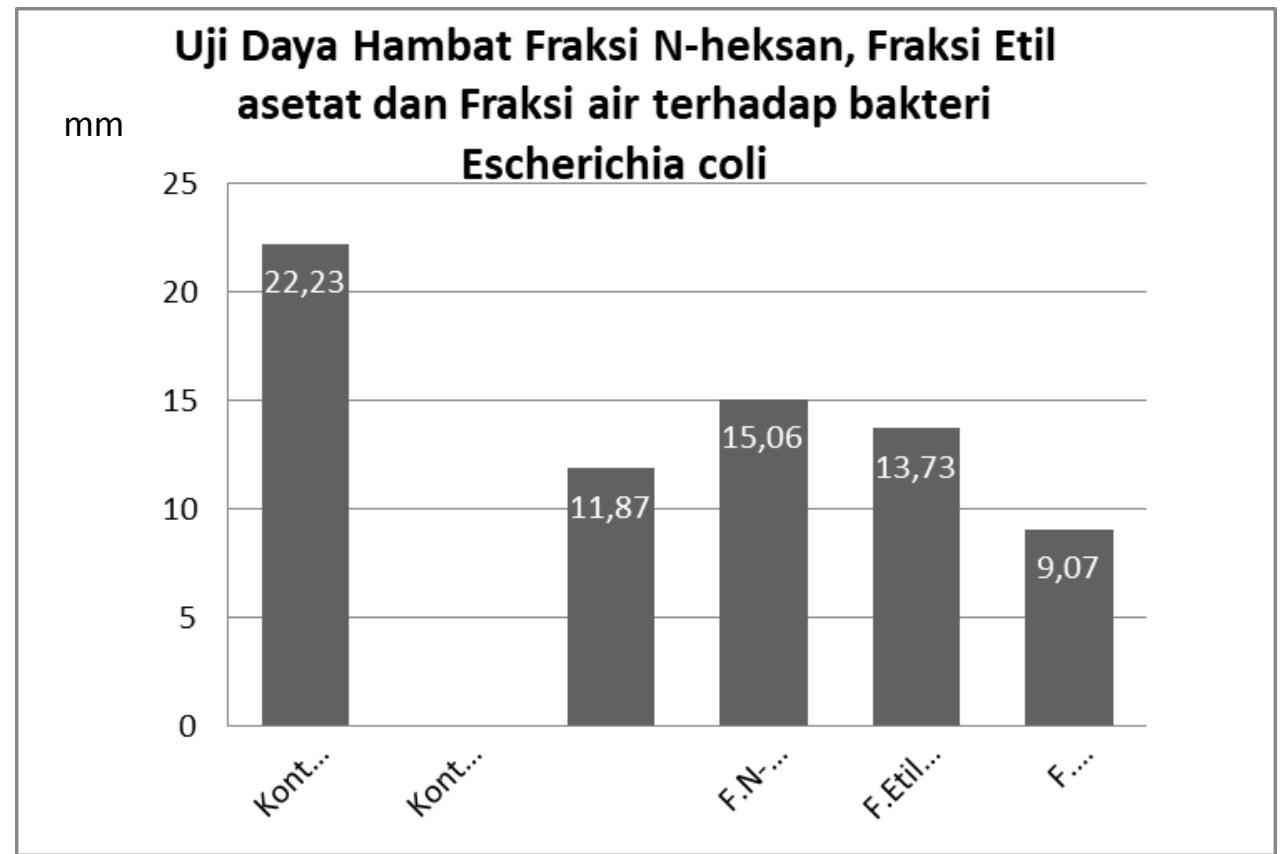

Gambar 2. Diagram uji Daya Hambat Fraksi N-heksan, Fraksi Etil asetat dan Fraksi air terhadap bakteri Escherichia coli

Penentuan uji daya hambat bertujuan untuk mengetahui fraksi mana yang bisa menghambat pertumbuhan bakteri. Penentuan daya hambat dilakukan dengan metode difusi cakram untuk menentuhkan uji daya hambat. Pada penelitian ini menggunakan kontrol positif kloramfenikol. Kloramfenikol merupakan antibiotik yang mempunyai aktifitas bakteriostatik dan pada dosis tinggi bersifat bakterisid. Aktivitas antibakterinya bekerja dengan menghambat sintesis protein dengan jalan meningkatkan ribosom subunit 50S yang merupakan langkah penting dalam pembentukan ikatan peptida. Kloramfenikol efektif terhadap bakteri aerob gram positif dan beberapa bakteri aerob gram negatif. 
Uji aktivitas antibakteri ekstrak etanol dan fraksi daun leunca terhadap bakteri Escherichia coli dan Staphylococcus aureus menggunakan metode difusi cakram karena difusi cakram relatif sederhana dan pengerjaannya cepat serta paling sering digunakan untuk menentuhkan kepekaan terhadap berbagai macam bakteri. Hasil daya uji antibakteri didasarkan pada pengukuran Diameter Daerah Hambat (DDH). Pertumbuhan bakteri yang terbentuk disekeliling kertas cakram. Bakteri yang digunakan pada penelitian ini sebelumnya dilakukan peremajaan bakteri untuk meregenerasi bakteri supaya dapat diperoleh bakteri yang muda dan tidak terkontaminasi. Media agar yang digunakan untuk peremajaan bakteri adalah Mouller Hinton Agar (MHA).

Metode pengujian yang dilakukan dengan media MHA yang sudah memadat dioleskan merata suspense bakteri dengan kapas steril, kemudian diamkan selama 15-30 menit, setelah itu dimasukan dish cakram yang kontrol positif (kloramfenikol), kontrol negatif (dmso), sampel uji ekstrak etanol daun leunca dan fraksi daun leunca dan fraksi dibuat dengan menimbang gram ekstrak kemudian dilarutkan dengan $1 \mathrm{ml}$ dmso setelah itu diinkubasi selama 24 jam.

Berdsarkan penelitian yang dilakukan terhadap empat perlakuan yaitu dengan menggunakan ekstrak etanol daun leunca, fraksi N-heksan, fraksi etil asetat dan fraksi aquadest diperoleh zona hambat yang berbeda-beda dan dapat dilihat dari zona hambat yang terbentuk, dan dari hasil analisa statistik yang telah dilakukan data menunjukan bahwa antara kelompok frkasi n-heksan, fraksi etil asetat dan fraksi aquadest dari data pada tabel satu dan tabel dua yang menunjukan adanya daya hambat tehadap bakteri Staphylococcus aureus dan Escherichia coli adalah fraksi n-heksan dilihat dari zona hambat setelah tiga kali pengulangan. Setelah itu fraksi etil asetat dan kemudian fraksi aquadest. Zona hambat yang terbentuk disebabkan karena adanya zat-zat aktif pada daun leunca yang mengandung senyawa yang bersifat antibakteri seperti alkaloid, flavonoid, dan tannin.

Berdasarkan hasil uji daya hambat dapat dilihat bahwa kontrol positif yang digunakan dapat menghambat pertumbuhan bakteri Staphylococcus aureus dan Escherichia coli sedangkan pada kontrol negatif dapat dilihat bahwa tidak terjadi pertumbuhan bakteri. Hasil selanjutnya fraksi n-heksan ekstrak daun leunca memiliki zona hambat terbesar terhadap bakteri Staphylococcus aureus yaitu dengan nilai rata-rata $11,32 \mathrm{~mm}$ dan terhadap bakteri Escherichia coli dengan diameter zona hambat yaitu 15,06 mm dan ini dapat dikategorikan termasuk ke range 10- $15 \mathrm{~mm}$ dapat dikatakan fraksi n-heksan termasuk lemah, kemudiameter zona hambat hasil fraksi etil asetat dan fraksi aquadest ekstrak daun leunca terhadap bakteri Staphylococcus aureus diatas termasuk kedalam kategori tidak ada karena berada di range $<10 \mathrm{~mm}$, tetapi pada uji daya hambat terhadap bakteri Escherichia coli mempunyai zona hambat tinggi setelah frkasi $\mathrm{n}$ heksan yaitu fraksi etil asetat dengan diameter zona hambat yaitu 13,73 mm termasuk kedalam kategori range lemah, kemudian hasil fraksi aquadest dengan diameter zona hambat 9,07 $\mathrm{mm}$ yang berarti tidak ada efektivitas terhadap bakteri Escherichia coli. Zona hambat yang terbentukdisebabkan karena adanya zatzat aktif pada daun leunca yang mengandung senyawa yang bersifat antibakteri seperti alkaloid, flavonoid dan tannin.

Mekanisme kerja alkaloid sebagai antibakteri adalah dengan cara menganggu komponen penyusun peptidoglikon pada sel bakteri sehingga lapisan dinding sel tidak terbentuk secara utuh dan menyebabkan kematian selain itu, alkaloid bekerja dengan mengganggu komponen penyusun peptidoglikon dan menghambat enzim topoimerase yang 
mempunyai peran sangat penting dalam proses replikas, transkripsi dan rekombasi DNA dengan cara memotong dan menyambung untai tunggal atau untai ganda DNA [7].

Mekanisme kerja aktivitas flavonoid sebagai antibakteri oleh kemampuan membentuk kompleks dengan ekstrak seluler dan protein-protein terlarut serta dinding sel bakteri sehingga bagian sel tersebut akan rusak dan kehilangan fungsinya. Beberapa flavonoid lifofilik mungkin juga merusak membran sel, pusat terjadinya beberapa reaksi enzimatis sehingga dapat menuju kepada kematian sel [7].

Mekanisme kerja antibakteri tannin mempunyai daya antibakteri dengan cara memprepitasi protein. Efek antibakteri tannin melalui reaksi dengan membran sel, inaktivasi enzim fungsi materi genetik. Mekanisme kerja tannin sebagai antibakteri adalah menghambat enzim reverse trancriptase dan DNA topoimerase sehingga sel bakteri tidak dapat terbentuk $[8]$.

Mekanisme kerja steroid sebagai antibakteri berhubungan dengan membran lipid dan sensitivitas terhadap komponen steroid yang menyebabkan kebocoran pada liposom [9].

Jika dilihat dari keseluruhan uji daya hambat tehadap bakteri Staphylococus aureu dan Escherichia coli yang ada efektivitas atau daya hambat yaitu hasil fraksi n-heksan ini dikarenakan senyawa yang ditarik fraksi n-heksan yaitu senyawa flavonoid karena penelitian sebelumya menunjukan jika senyawa flavonoid dapat menghambat bakteri Staphylococcus aureus dan Escherichia coli. Dari penjelasan diatas dapat dikatakan hasil fraksi yang paling memilki efektivitas antibakteri yaitu hasil fraksi n-heksan terhadap kedua bakteri diatas Karena diameter rata-rata nya berkisaran 10-15 mm sudah dapat dikatakan memilki aktivitas antibakteri walaupun masih dalam range $10-15 \mathrm{~mm}$ termasuk lemah.

\section{KESIMPULAN}

Berdasarkan hasil penelitian yang telah dilakukan maka dapat disimpulkan bahwa semua fraksi ekstrak positif mempunyai daya hambat pertumbuhan bakteri Escherichia coli dan Staphylococcus aureus. Aktivitas terbesar dalam menghambat pertumbuhan bakteri Escherichia coli dan Staphylococcus aureus adalah fraksi n-heksan daun leunca (Solanum nigrum $L$ ).

\section{DAFTAR RUJUKAN}

1. Eliza, N., Pengaruh Pemberian Madu Terhadap Bakteri Staphylococcus aureus dan Escherichia coli, Fakultas Kedokteran dan Ilmu Kesehatan, Universitas Islam Negeri Syarif Hidayatullah, Jakarta, 2010.

2. Radji, Maksum. Peranan Bioteknologi dan Mikroba Endofit dalam Pengembangan Obat Herbal. Majalah Ilmu Kefarmasian, 2005, Vol II no3:113-126

3. Jain R, Sharma A, Gupta S, Sarethy IP, Gabrani R, Solanum nigrum: Current Perspectives on Therapeutic Properties. Alternatif Medicine Review, LLC. 16 (1):2011, 78-85.

4. Karmakar, U.K.,U.K. Tarafder,S.K.sadhu, N.N. biswas, M.C shill. Biological investigation of dried fruit of solanum nigrum Linn. S J. Pharmsci. 2010,3(1):38-45. 
5. Subashini, Rajakannu . Comparative Evaluation of Antimicrobial Activity of Selected Three Herbal Plants Extrac With Digital Image Processing Technique. Department of Biomedical Engineering, SSN Collsfe of Engineering. 2013, (2):14-26

6. Campbell, Biologi Jilid I. Edisi VIII. Erlangga : Jakarta, 2010.

7. Cowan, M. Murphy, Plants Product as Antimicrobial Agents. J. Microbiology Review. 1999, 12 (4) : 564:582.

8. Nuria, Uji Aktivitas Antibakteri Ekstrak Etanol Daun Jarak Pagar (Jatropha curcas L) Terhadap Bakteri Staphylococcus aureus ATCC 25923, Escherichia coli ATCC 25922 dan Salmonella typhy ATCC 1408.Ilmu-ilmu Pertanian, 2009, 5(2) : 26-37.

9. Madduluri. Invitro Evaluation Antibacterial Activity of Five Indegenous Plants Extract Agains Five Bacterial Phatogens of Human. International Journal of Pharmacy and Pharmaceutical Science. 2013, 5 (4 : 679-684). 